\title{
TITLE:
}

\section{A new Species of Labiosthenolepis (Sigalionidae: Polychaeta)}

$\operatorname{AUTHOR}(\mathrm{S})$ :

AUNGTONYA, CHARATSEE

\section{CITATION:}

AUNGTONYA, CHARATSEE. A new Species of Labiosthenolepis (Sigalionidae: Polychaeta). Publications of the Seto Marine Biological Laboratory. Special Publication Series 2007, 8: 103-114

\section{ISSUE DATE:}

2007

URL:

http://hdl.handle.net/2433/70905

RIGHT: 


\title{
A new Species of Labiosthenolepis (Sigalionidae: Polychaeta)
}

\author{
Charatsee Aungtonya
}

Phuket Marine Biological Center, P.O. Box 60, Phuket 83000, Thailand

Author's e-mail: charatsee@yahoo.com

\begin{abstract}
Labiosthenolepis andamanensis sp. nov. is described from the Andaman Sea, southwestern Thailand, and from Tanabe Bay, Japan. The bulk of the samples were collected from the Andaman Sea during the 'Effects of Offshore Tin Mining Project' in 1980-1982. Labiosthenolepis andamanensis differs from L. laevis (McIntosh, 1885) by having oval, thin, flattened labial lobes and stylodes on the dorsal sides of segment 1 , whereas in the latter species the labial lobes are thick, fleshy, lobulate, without stylodes on the dorsal sides of segment 1 . The new species also differs from L. sibogae (Horst, 1917) by having dorsal tubercles on segment 3 , which are absent in the latter species.
\end{abstract}

Key words: Sigalionidae, Labiosthenolepis, Andaman Sea, Thailand, Tanabe Bay, Japan

\section{Introduction}

Sigalionid polychaetes from the Andaman Sea were first published by Phasuk (1992), in a checklist with information on their distribution but without descriptions or comments. Aungtonya (2002) made a preliminary study of sigalionids species found in the Andaman Sea and a more detailed study of Sigalionidae from the Andaman Sea has been undertaken and will be published in a forthcoming paper (Aungtonya, unpublished data).

Of the total 789 specimens from the Andaman Sea, there were about 26 species representing 14 genera (Aungtonya, unpublished data). The most abundant was Labiosthenolepis. The genus is characterized by having compound neurochaetae spinigers, ceratophore of median antenna with lateral auricles, long style of median antenna, inner tentacular lobes and dorsal tentacular crests, lateral lips of mouth with labial lobes, and elytra with smooth surface and outer lateral margin without papillae. Two species of Labiosthenolepis have been recognized (Imajima, 2005, 2006; Pettibone, 1992). Labiosthenolepis laevis (McIntosh, 1885) was described based on specimens from the Pacific region. Labiosthenolepis sibogae (Horst, 1917) was described based on specimens from the Indo-Pacific region.

\section{Materials and Methods}

Samples from the Andaman Sea were collected during the Fifth Thai-Danish Expedition in 1966 (Thai-Danish), the 'Effects of Offshore tin mining on benthic communities Project 1980-1982' (TinMining), the Thai-Danish BIOSHELF project 1996-2000 (BIOSHELF), with additional samples from a quantitative survey on the benthic fauna along the west coast of Thailand (QuantitativeSurvey) (Figs. 1, 2) and Chalong Bay (ChalongBay).

Examinations were carried out using a Nikon SMZ-U stereomicroscope, a Nikon E600 compound microscope and for illustrations, a camera lucida. The specimens were stained with Shirlastain (Petersen, 1998). Body width was measured at segments 10-15. The maximum number of segments was counted. Parapodia were removed from the left side of the body and illustrated in posterior and anterior views. Neurochaetae were illustrated from the same parapodia. Elytra were also removed from 


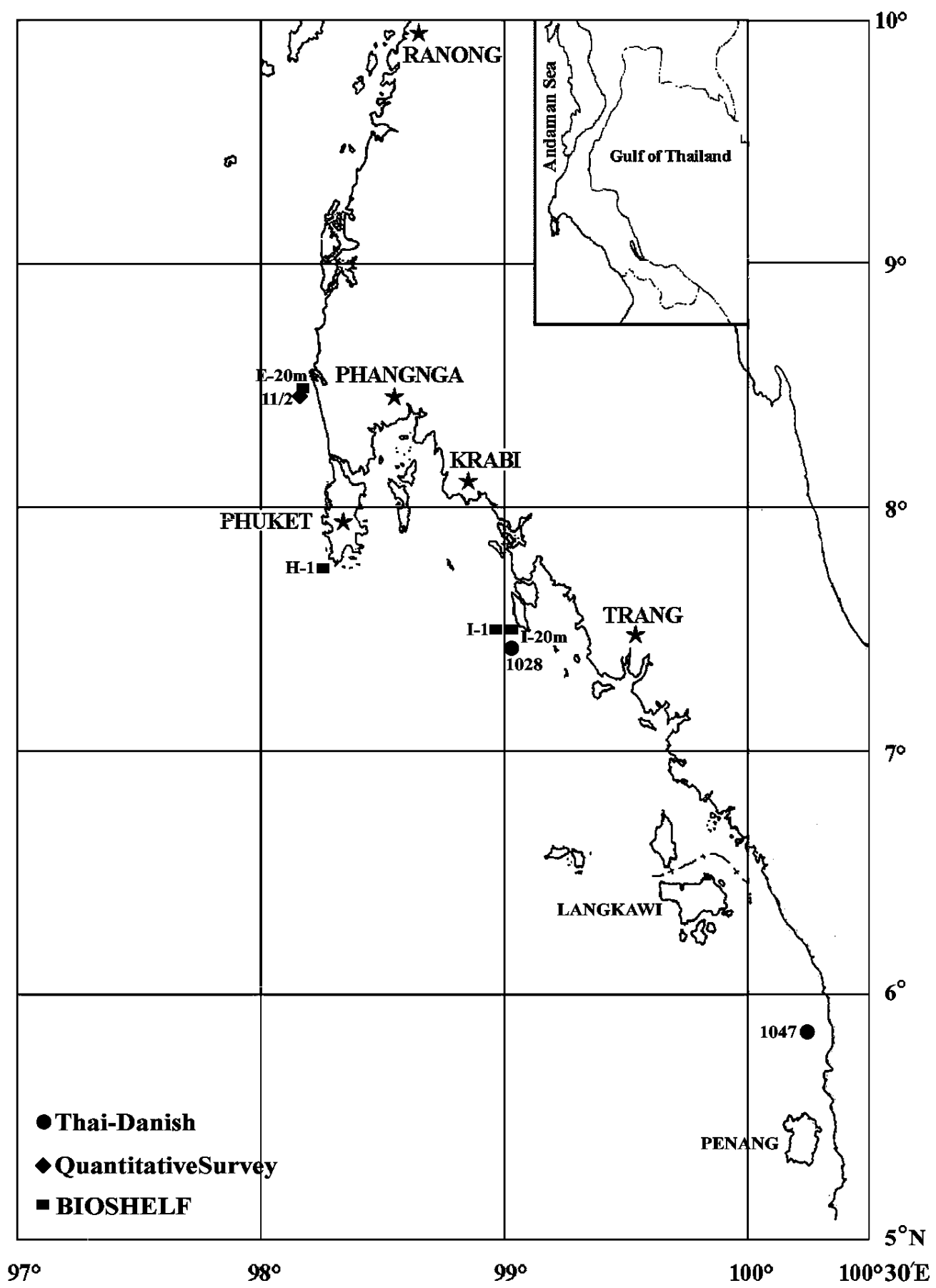

Fig. 1. The location of the sampling stations of the Thai-Danish (the Fifth Thai-Danish Expedition), QuantitativeSurvey (the quantitative survey along the west coast of Thailand), and BIOSHELF (the Biodiversity of the Andaman Sea Shelf Project) in the Andaman Sea, southwestern Thailand. 


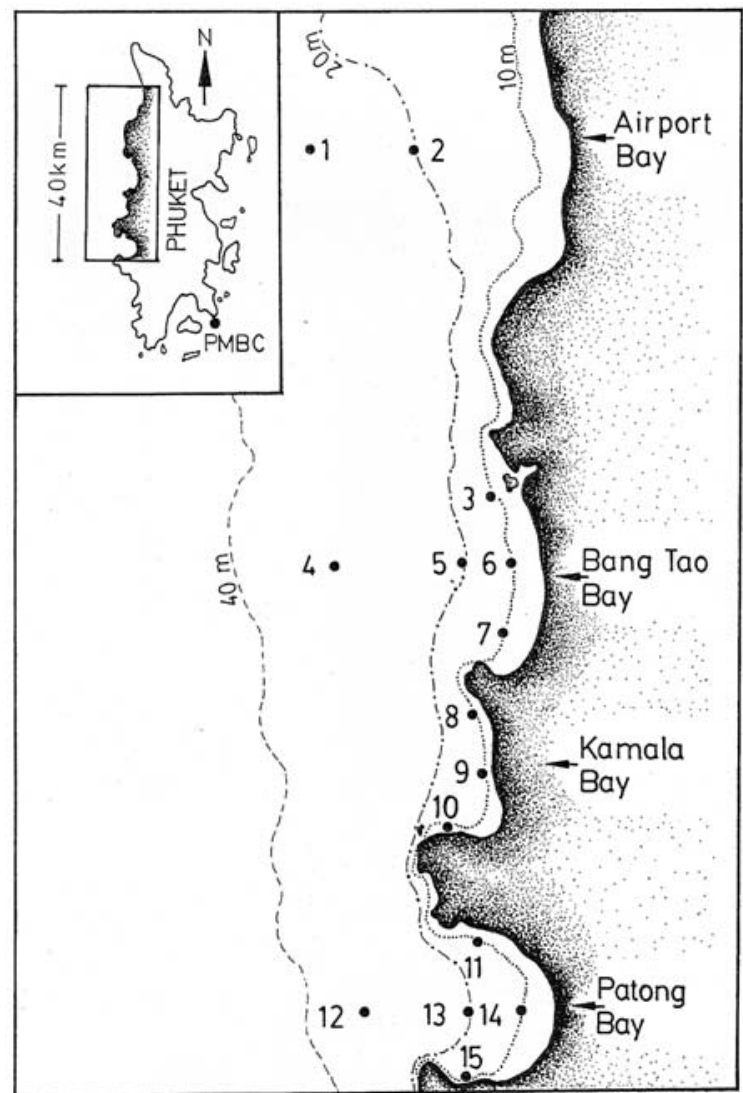

Fig. 2. Sampling stations of the 'Effects of Offshore Tin Mining Project' in four bays on the west coast of Phuket Island during 1980-1982 (Hylleberg, Nateewathana and Bussarawit, 1985; Hylleberg, Nateewathana and Chatananthawej, 1985).

the left side and illustrated in dorsal view. SEM specimens were dehydrated before being "critical point' dried, sputter-coated with gold and examined in a JSM-5800 scanning electron microscope.

Samples of Japanese sigalionids were collected from Tanabe Bay (TanabeBay) (Fig. 3). Photographs of living specimens were taken with a Nikon Coolpix 4500. Specimens for SEM study were fixed in 1-2\% osmium tetroxide in filtered seawater for about an hour, rinsed, and stored in distilled water, transferred to ethanol, freeze dried, sputter coated with platinum, and examined in a Hitachi S-4300.

The specimens are deposited in the Reference Collection at Phuket Marine Biological Center, Thailand (PMBC), Seto Marine Biological Laboratory, Kyoto University, Japan (SMBL), and the Zoological Museum, Copenhagen University, Denmark (ZMUC).

Abbreviations used in the figures are acl: acicular lobe; au: auricle; buc: buccal cirrus; dtcr: dorsal tentacular crest; dtu: dorsal tubercle; itl: inner tentacular lobe; ipas: inner palpal sheath; lal: labial lobe on lateral lip; man: median antenna; opas: outer palpal sheath; st: stylode. 


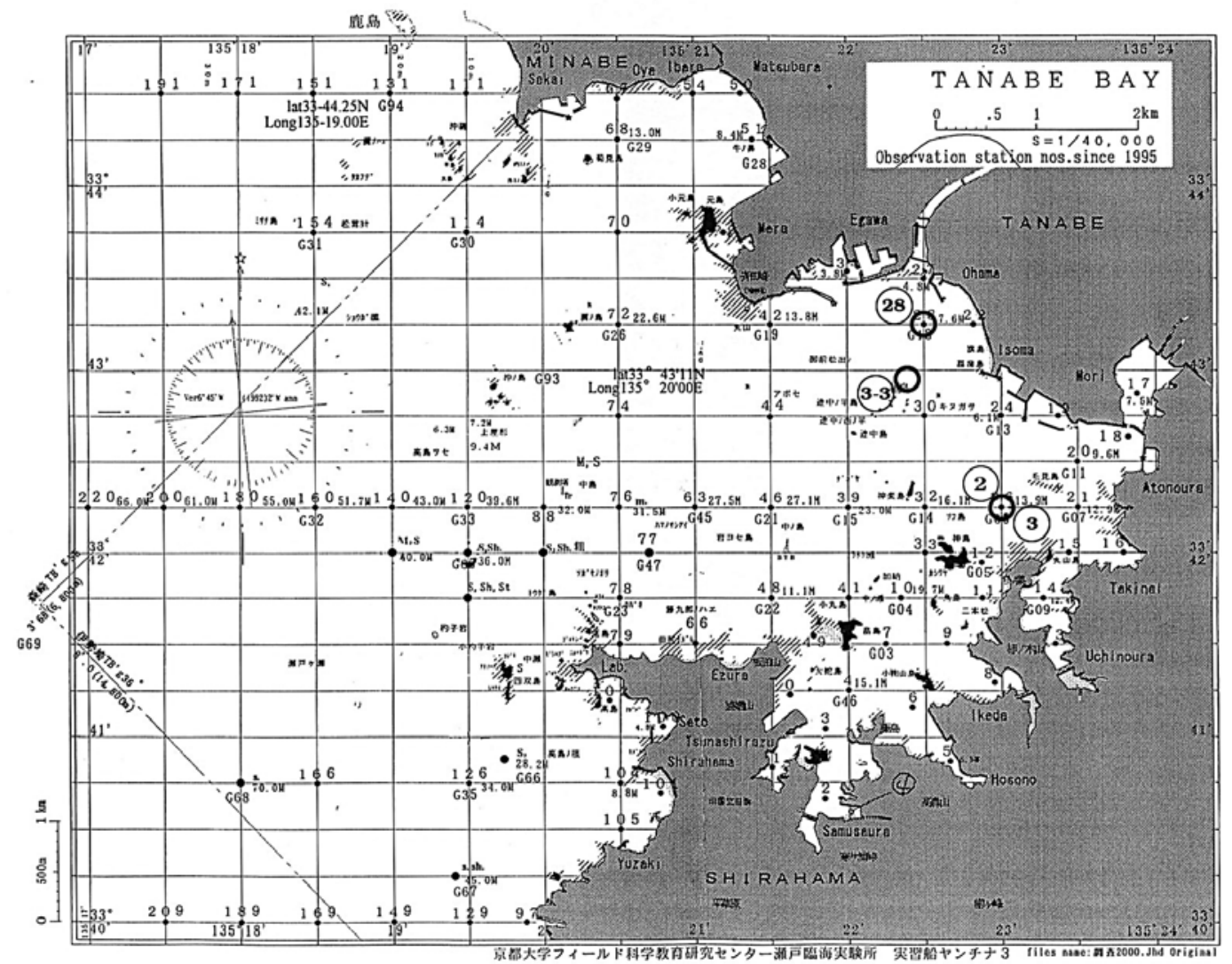

Fig. 3. The location of the sampling stations of Tanabe Bay, Japan (Note St. 2 and St. 3 are at the same position but were sampled during two different cruises).

\section{Sources of material}

\section{The Fifth Thai-Danish Expedition}

The samples of the Fifth Thai-Danish Expedition were collected during January-March 1966 using the research vessel 'M/S Dhanarajata' (the Fisheries Research Vessel No. 2 of the Fisheries Department) (Seidenfaden et al., 1968; Phasuk, 1992). The surveys covered the area from the shore to about $80 \mathrm{~m}$ depth, along the west coast of Thailand, between the boundaries with Burma in the north and Malaysia in the south. The polychaete material comprised 3284 specimens, preliminarily assigned to 39 families, 111 genera and 154 species. Some of the polychaetes appeared to represent undescribed species (Phasuk, 1992).

\section{The 'Effects of Offshore Tin Mining Project'}

The project on the effects of offshore tin mining on the marine benthos of the west coast of Phuket was carried out from April 1980 to June 1982. The material was collected from 15 stations down to a depth of $30 \mathrm{~m}$ (Fig. 2). The bulk of the polychaetes from this project were sorted into family (but not identified further) and kept at the Reference Collection, PMBC. 


\section{The quantitative survey along the west coast of Thailand}

A quantitative survey on the benthic fauna along the west coast of Thailand was carried out by the PMBC during March-April 1982 and January-February 1983, using the research vessel Pramong 8. The survey attempted to cover the area from the shore down to a depth of about $75 \mathrm{~m}$, covering the area between the borders of Burma in the north and Malaysia in the south. The results indicated that polychaetes were the most abundant group found in terms of the number of individuals (Chantananthawej and Bussarawit, 1987).

\section{The Biodiversity of the Andaman Sea Shelf Project}

The Biodiversity of the Andaman Sea Shelf (BIOSHELF) Project during 1996-2000 attempted to cover the west coast of Thailand, from the Burmese border in the north to the Malaysian border in the south. The objective of the project was to expand the general knowledge of the diversity of benthos at depths down to $1000 \mathrm{~m}$ within the Thai Economic Exclusive Zone (EEZ) and to provide additional specimens for the PMBC Reference Collection. Samples were taken at depths of 20-900m, with extra stations that were not part of the original transects A-L sampled during the UNOCAL cruise. For a report on the itinerary of the BIOSHELF surveys was see Aungtonya et al., 2000. A part of the BIOSHELF polychaete material was studied during the PMBC-DANIDA International Workshop on Polychaetes, held at the PMBC during June-August 1997. The proceedings (Phuket Marine Biological Center Special Publication no. 24: 2002) documents polychaetes belonging to 17 families, 84 genera and 185 species (132 named), and among these, 4 of the genera and 43 species were found to be new (Eibye-Jacobsen, in the Editor's Foreword).

\section{Chalong Bay}

The field survey was mainly conducted in the inner Chalong Bay on Phuket Island, the Andaman Sea, Thailand. Materials were collected during 24-31 October 2006, using the boat of the Fisheries Department. A benthic survey in Chalong Bay covered the area encompasses the 3 Tambons Wichi, Chalong and Rawai.

\section{Tanabe Bay}

In December 2003, I was jointly funded by the Global Taxonomic Initiative (GTI) and Natural Geography in Shore Areas (NaGISA) Programs to visit the Seto Marine Biological Laboratory (SMBL, Japan). Japanese sigalionids had been collected by Dr. Tetsuya Kato (SMBL), and he further accompanied me on two additional surveys in Tanabe Bay on board the R/V Janthina III, where we collected material using a Smith-McIntyre grab.

\section{Taxonomy}

Family Sigalionidae Kinberg, 1856

Genus Labiosthenolepis Pettibone, 1992

Labiosthenolepis andamanensis sp. nov. Figs. 4A-B, 5A-D, 6A-G; 7A-F, 8A-H, Table 1

Sthenolepis yhleni. - Phasuk, 1992: 81, part (st. 1047 according to label, not cited in Phasuk 1992), not Labioleanira yhleni (Malmgren, 1867).

Labiosthenolepis cf. sibogae. - Aungtonya, 2002: 221-222, figs. 9-10, not L. sibogae (Horst, 1917).

Holotype

TinMining I: st. 12/2, Patong Bay, central part, 30 m, 10 Apr 1980 (holotype, PMBC 20330) 


\section{Paratype}

TinMining I: st. 12/2, Patong Bay, central part, 30 m, 10 Apr 1980 (2 paratype, PMBC 20321); TinMining II: st. 1/2, Airport Bay, 30 m, 29 June 1981 (3 paratypes, PMBC 20350); TinMining III: st. 12/1, Patong Bay, central part, 30 m, 17 Sep 1980 (1 paratype, ZMUC-POL-1714); BIOSHELF: st. E20m/OS, $8^{\circ} 30^{`} \mathrm{~N}$, 98 12`E, $20 \mathrm{~m}$, muddy sand, 22 Apr 1996 (1 paratype, PMBC 20355); ChalongBay st. $7 / \mathrm{G}, 7^{\circ} 48^{\prime} \mathrm{N}, 98^{\circ} 23^{\prime} \mathrm{E}, 12 \mathrm{~m}$, mud, 25 Oct 2006 (1 paratype, PMBC 21343); TanabeBay: st. 3, $33^{\circ} 42.25^{\circ} \mathrm{N}, 135^{\circ} 23.00^{`} \mathrm{E}, 14.2 \mathrm{~m}$, mud, 4 Dec. 2003 (2 paratypes, PMBC 20733; 1 paratypes, ZMUCPOL-1839; 2 spec. on SEM-stub, SMBL Type No. 423); st. 28, off Aizu-gawa river mouth, $33^{\circ} 43.25^{\prime} \mathrm{N}, 135^{\circ} 22.50^{\prime} \mathrm{E}, 7.6 \mathrm{~m}$, mud, 20 May 2003 (1 paratype, PMBC 20736); Tanabe Bay, $33^{\circ} 42.95^{`} \mathrm{~N}, 135^{\circ} 22.40^{`} \mathrm{E}, 12$ Sep. 2003 (2 paratypes, PMBC 20735); st. $2,33^{\circ} 42.25^{`} \mathrm{~N}, 135^{\circ} 23.00^{`} \mathrm{E}$, mud, 14 m, 17 Oct 2003 (2 paratypes, PMBC 20734; 2 paratypes, SMBL Type No. 424).

\section{Material examined}

Thai-Danish: st. 1028 , haul 2, $7^{\circ} 26^{\prime} \mathrm{N}, 9^{\circ} 01^{\prime} \mathrm{E}, 27 \mathrm{~m}$, clayey mud, 19 Jan 1966 (1, PMBC 20362); st. 1047 , haul $10,5^{\circ} 43^{\prime} \mathrm{N}, 100^{\circ} 13^{\prime} \mathrm{E}, 15 \mathrm{~m}$, loose clay with shells, 26 Jan 1966 (1, PMBC 20363); TinMining I: st. 1/1, Airport Bay, 30 m, 26 Apr 1982 (2, PMBC 20351); st. 1/2, Airport Bay, 30 m, 26 Apr 1982 (4, PMBC 20352); st. 1/3, Airport Bay, 30 m, 9 Apr 1980 (3, PMBC 20364); st. 1/3, Airport Bay, 30 m, 24 Apr 1982 (1, PMBC 20368); st. 3/1, Bang Tao Bay, northern part, 10 m, 9 Apr 1980 (2, PMBC 20365; 1 spec. on SEM-stub, PMBC 15811); st. 3/2, Bang Tao Bay, northern part, 10 m, 9 Apr 1980 (1, PMBC 20323); st. 3/3, Bang Tao Bay, northern part, 10 m, 9 Apr 1980 (2, PMBC 20324); st. 4/1, Bang Tao Bay, central part, 30 m, 9 Apr 1980 (5, PMBC 20325); st. 4/1, Bang Tao Bay, central part, 30 m, 26 Apr 1982 (3, PMBC 20370); st. 4/2, Bang Tao Bay, central part, 30 m, 9 Apr 1980 (1, PMBC 20326); st. 5/2, Bang Tao Bay, central part, 20 m, 9 Apr 1980 (1, PMBC 20327); st. 5/2, Bang Tao Bay, central part, 20 m, 26 Apr 1982 (3, PMBC 20353); st. 5/3, Bang Tao Bay, central part, 20 m, 9 Apr 1980 (2, PMBC 20328); st. 5/3, Bang Tao Bay, central part, 20 m, 26 Apr 1982 (1, PMBC 20371); st. 6/3, Bang Tao Bay, central part, 10 m, 9 Apr 1980 (1, PMBC 20329); st. 12/1, Patong Bay, central part, 30 m, 26 Apr 1982 (1, PMBC 20354); st. 14/1, Patong Bay, central part, 10 m, 26 Apr 1982 (2, PMBC 20374; 2, SMBL Inv-10001); TinMining II: st. 1/3, Airport Bay, 30 m, 18 June 1982 (4, PMBC 20369); st. 5/2, Bang Tao Bay, central part, 20 m, 10 June 1980 (1, PMBC 20331); st. 6/1, Bang Tao Bay, central part, 10 m, 10 June 1980 (4 spec. on SEM-stubs, PMBC 20300, PMBC 20301, PMBC 20302, PMBC 20303); st. 8/1, Kamala Bay, northern part, 10 m, 11 June 1980 (1, PMBC 20336); st. 8/2, Kamala Bay, northern part, 10 m, 11 June 1980 (1, PMBC 20337); st. 12/3, Patong Bay, central part, 30 m, 18 June 1982 (2, PMBC 20373); st. 13/2, Patong Bay, central part, 20 m, 11 June 1980 (1, PMBC 20338); st. 14/2, Patong Bay, central part, 10 m, 11 June 1980 (1 spec. on SEM-stub, PMBC 20299); TinMining IV: st. 1/3, Airport Bay, 30 m, 15 Oct 1980 (1, PMBC 20341); TinMining V: st. 1/2, Airport Bay, 30 m, 15 Dec 1980 (5, PMBC 20342); st. 4/2, Bang Tao Bay, central part, 30 m, 15 Dec 1980 (1, PMBC 20343); TinMining VI: st. 1/2, Airport Bay, 30 m, 20 Feb 1981 (1, PMBC 20345); st. 4/2, Bang Tao Bay, central part, 30 m, 20 Feb 1981 (1, PMBC 20346); st. 5/3, Bang Tao Bay, central part, 20 m, 20 Feb 1981 (1, PMBC 20356); st. 7/1, Bang Tao Bay, southern part, 10 m, 20 Feb 1981 (3, PMBC 20372); QuantitativeSurvey: st. 11/2, 4, 33 m, 2 Feb 1983 (1, PMBC 20366); BIOSHELF: st. E-20m/OS, $8^{\circ} 30^{`} \mathrm{~N}, 9^{\circ} 12^{`} \mathrm{E}, 20 \mathrm{~m}$, muddy sand, 22 Apr 1996 (1 spec. on SEM-stub, PMBC 19640); st. H-1/BC, $7^{\circ} 45^{`} \mathrm{~N}, 9^{\circ} 16^{`} \mathrm{E}, 32 \mathrm{~m}$, sandy mud, 9 May 1996 (1, ZMUC-POL-1715); st. H-1/OS, 746`N, 98¹6`E, 40 m, soft mud, 20 Feb 1998 (2, PMBC 20357; 1 spec. on SEM-stub); st. I-20m/BC, $7^{\circ} 30^{`} \mathrm{~N}, 9^{\circ} 01^{`} \mathrm{E}, 21 \mathrm{~m}$, mud, 3 May 1996 (2, PMBC 20358); st. I20m/OS, $7^{\circ} 30^{\prime} \mathrm{N}, 9^{\circ} 01^{`} \mathrm{E}, 21 \mathrm{~m}$, mud, 3 May 1996 (3, PMBC 20359); st. I-1/OS, $7^{\circ} 30^{\prime} \mathrm{N}, 9^{\circ} 57^{`} \mathrm{E}, 38$ m, mud, 3 May 1996 (1, PMBC 15810); st. I-1/OS, 7³0`N, 9855`E, 42 m, mud, 22 Feb 1998 (2, PMBC 20360).

\section{Description}

Largest specimen incomplete and in 2 pieces, anterior piece about $11 \mathrm{~mm}$ long (with about 47 
segments), in total about $32 \mathrm{~mm}$ long, with about 117 segments and $4.2 \mathrm{~mm}$ wide including chaetae (holotype, PMBC 20330). Specimen complete, about $45 \mathrm{~mm}$ long (with about 110 segments) and about $3 \mathrm{~mm}$ wide including chaetae (paratype PMBC 20736). Prostomium oval, wider than long, dorsally fused with tentacular parapodia, two pairs of small eyes arranged in a square (Fig. 4A). Ceratophore of median antenna stout, with prominent lateral auricles, located on anterior of prostomium; style long; lateral antennae short, fused with dorsal side of tentacular parapodia, without ceratophore (Figs. 4A, 5A, 6A-B, D, 7A-C, 8A). Dorsal tentacular crests present, ciliated ridges with small anterior lobe. Inner tentacular lobes elongate-conical, median ciliated ridge not observed. One or two stylodes between lateral antenna and base of dorsal tentacular cirrus. Lateral lips of mouth with flattened, tongue-like labial lobes (Figs. 4B, 5C, 6C, 7D-E, 8B). Segment 2 with ventral buccal cirri. Palps extend to segment 10-14, with large inner palpal sheaths and shorter outer palpal sheaths. Segment 3 with small dorsal tubercles, bearing distal papilla (Figs. 5A-B, 6E, 7A). Branchiae begin at about segment 7-9. Ventral cirri short, tapered, with outer basal knob. Articulation on the tip of ventral cirri appear only on the anterior end and not on the posterior segments. Elytra oval, covering mid-dorsum, except anterior and posterior ends (Figs. 6A, 8H). Pygidium with terminal anus and pair of long anal cirri (Fig. 6G). Notopodia with posterior upper lobe and anterior lower lobes, anterior upper lobe inconspicuous, and including a large stylode near tip of acicular lobe. Notochaetae simple, coarse to finely spinous capillaries. Neuropodia with posterior upper and lower lobes enclosing base of chaetae; anterior upper lobe indistinct, lower lobe inconspicuous, fimbrated (Fig. 8C-D). Parapodial stylodes present. Neurochaetae compound spinigers with canaliculate blades of differing length, lower group with slightly shorter blades (Figs. 5D, 6F, 7F, 8E-G), and blades becoming shorter in more posterior parapodia; simple neurochaetae absent.

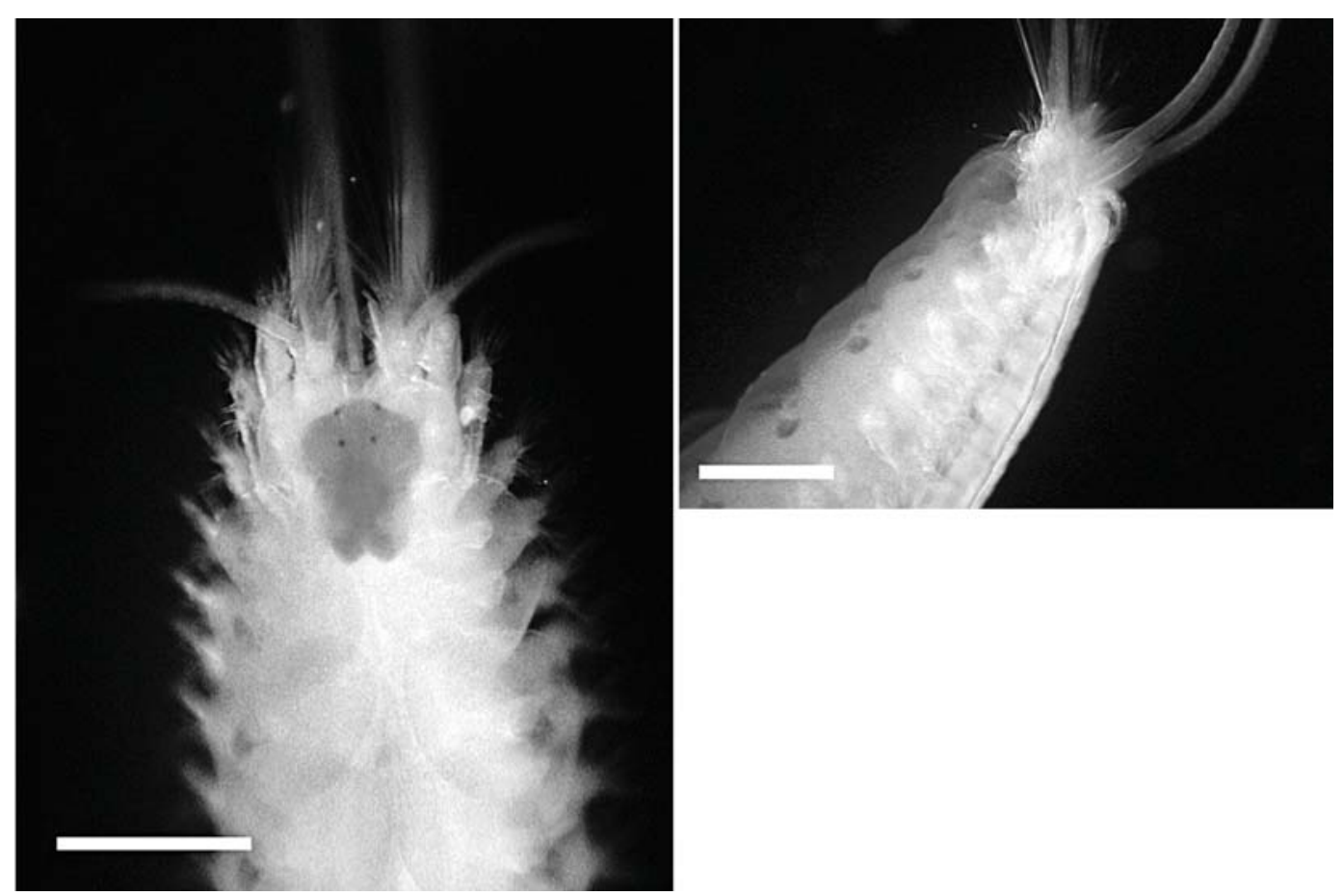

Fig. 4. Labiosthenolepis andamanensis sp. nov., living specimen from Tanabe Bay: A. anterior end, dorsal view; B. Anterior end of same, anterodorsal view. Scale bars $=500 \mu \mathrm{m}$. 


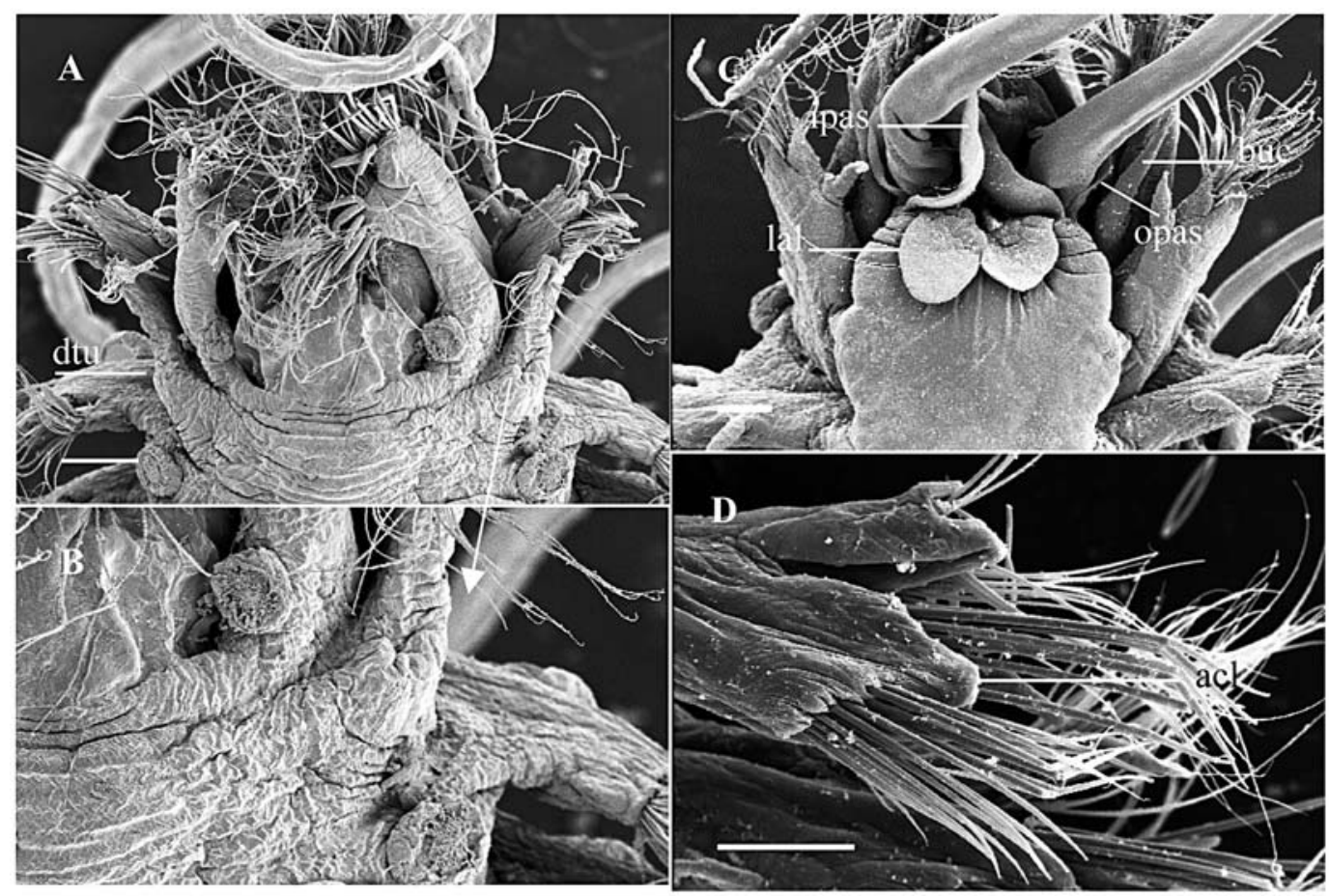

Fig. 5. Labiosthenolepis andamanensis sp. nov.: A. Anterior end, dorsal view, style of median antenna lost; B. Enlargement of dorsal surface of segment 3 in A; C. Anterior end, ventral view; D. Parapodium of anterior region, anteroventral view. SEM micrographs of PMBC 19640. Scale bars $=100 \mu \mathrm{m}$ (A, C-D).

\section{Etymology}

This species is named for the Andaman Sea.

\section{Distribution}

Andaman Sea, Thailand, 10-42 m, mud or mud with sand and shells; Tanabe Bay, West Pacific coast, Honshu, Japan, 7.6-14.2 m.

\section{Remarks}

The characters of Labiosthenolepis andamanensis differs from L. laevis as described and figured by Pettibone (1992) by having oval, thin, flattened labial lobes and stylodes on the dorsal sides of the segment 1 , whereas in the latter species the labial lobes are thick, fleshy, lobulate, without stylodes on the dorsal sides of segment 1 . The general characters of Labiosthenolepis andamanensis closely resemble those of $L$. sibogae, as described by Pettibone (1992, largest syntype about $4 \mathrm{~mm}$ wide). However, in the present species dorsal tubercles are present on segment 3 and the elytra covers or nearly covers the mid-dorsum, except anteriorly. In L. sibogae such tubercles are absent and the elytra leave the mid-dorsum uncovered (Table 1). Pettibone (1992) used characters of 1) the length of the blade of compound spinigerous neurochaetae in the middle parapodia and 2) the articulation on the tip of ventral cirri to distinguish between L. laevis and L. sibogae. Labiosthenolepis sibogae has long blades of compound spinigerous neurosetae in the middle parapodia and articulation on the tip of ventral cirri, whereas the blades in L. laevis are short and the articulation on the tip of ventral cirri was not reported. Imajima (2005) confirmed the shorter length of the blade of compound spinigerous 


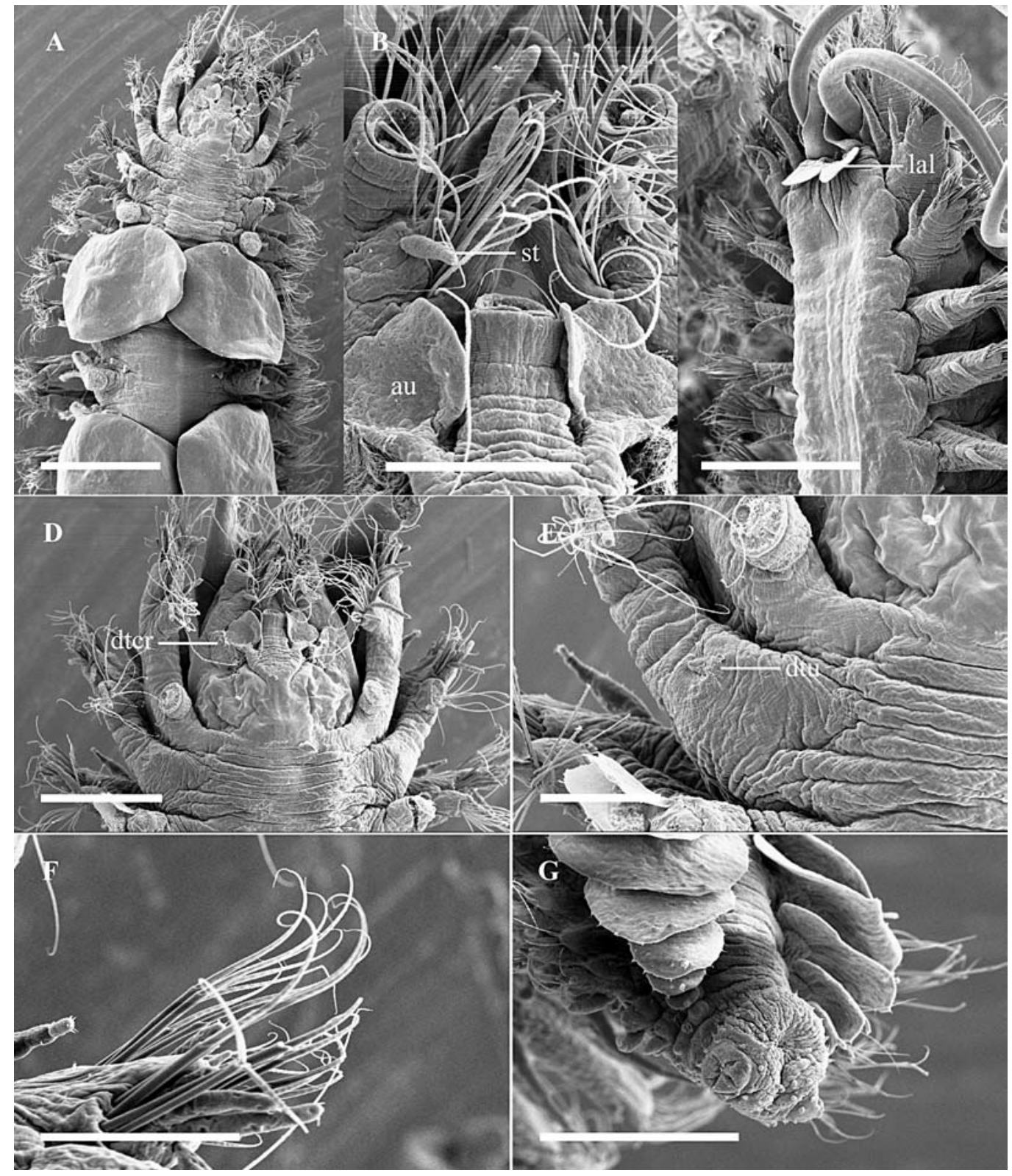

Fig. 6. Labiosthenolepis andamanensis sp. nov.: A. Anterior segments, dorsal view, style of median antenna lost; B. Close-up of auricles; C. Anterior segments, ventral view; D. Anterior end, dorsal view; E. Close-up on dorsal surface of segment 3; F. Parapodium from middle region, anteroventral view; G. Posterior end, dorsolateral view, anal cirri lost. - SEM micrographs of SMBL Type No. 423 (1st specimen shows dorsal side: A-B, D-G; 2nd specimen shows ventral side: C). Scale bars $=500 \mu \mathrm{m}$ (A, C), $250 \mu \mathrm{m}$ (D), $200 \mu \mathrm{m}$ (G), $100 \mu \mathrm{m}(\mathrm{B}, \mathrm{E}-\mathrm{F})$. 


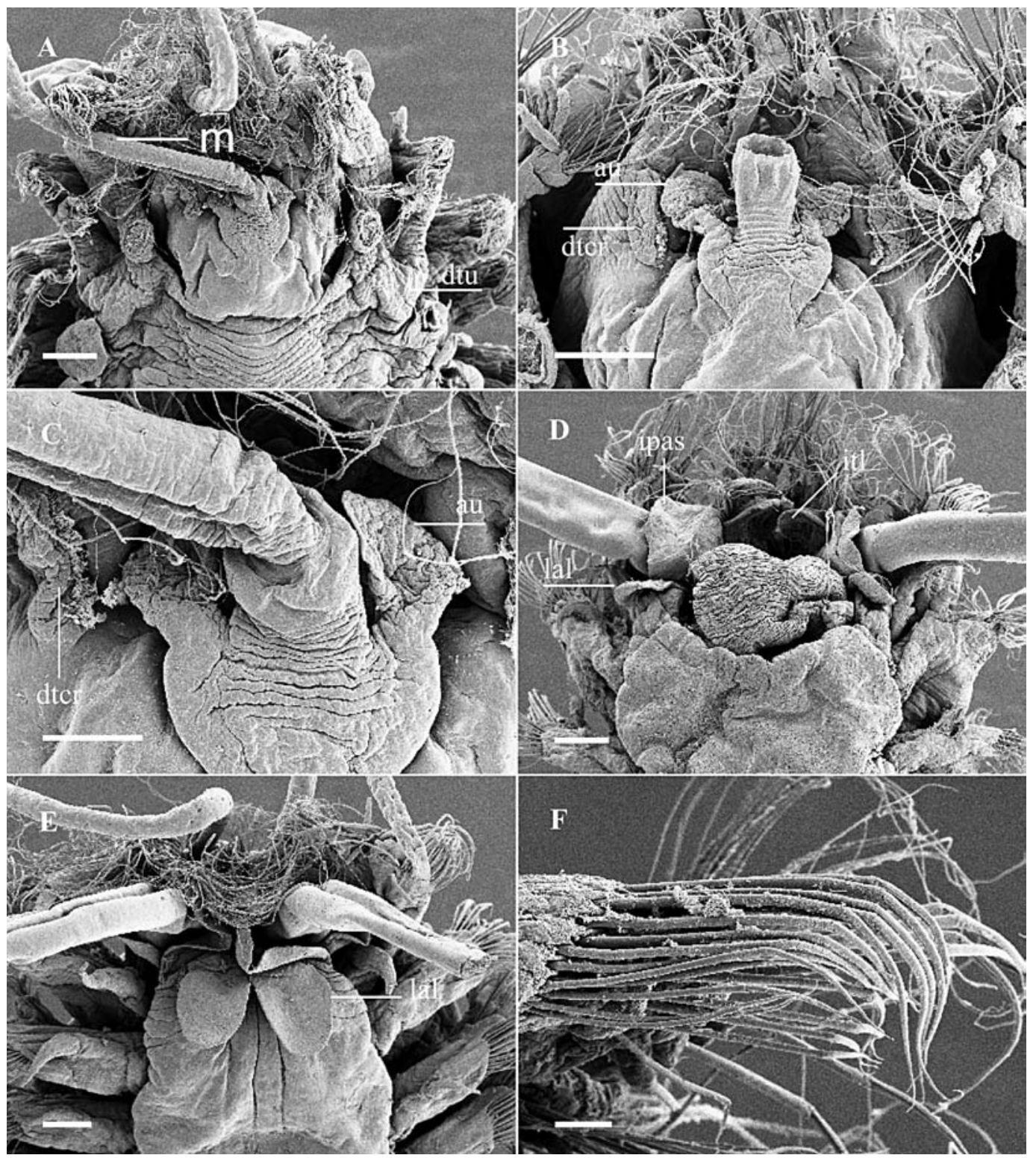

Fig. 7. Labiosthenolepis andamanensis sp. nov.: A. Anterior end, dorsal view; B. Anterior end, dorsal view, style of median antenna lost; C. Close-up of auricles; D-E. Anterior end, ventral view; F. Neuropodium with compound spinigers, from anterior region, anteroventral view. SEM micrographs of PMBC 20300 (B, D), PMBC 20301 (F), PMBC 20302 (E), PMBC 20303 (A, C). Scale bars = $100 \mu \mathrm{m}$ (A-B, D-E), $50 \mu \mathrm{m}$ (C), and $20 \mu \mathrm{m}(\mathrm{F})$.

neurochaetae in the middle parapodia in L. laevis. Articulation on the tip of ventral cirri appear only on the anterior end, and is absent on the posterior segments. However, Imajima (2006) did not report the difference of these characters from the anterior and posterior parapodia in L. sibogae. Therefore, these characters are not included in Table 1. In $L$. andamanensis, these two characters resemble those of $L$. laevis, as described by Imajima (2005). Blades of compound spinigerous neurosetae in the middle 


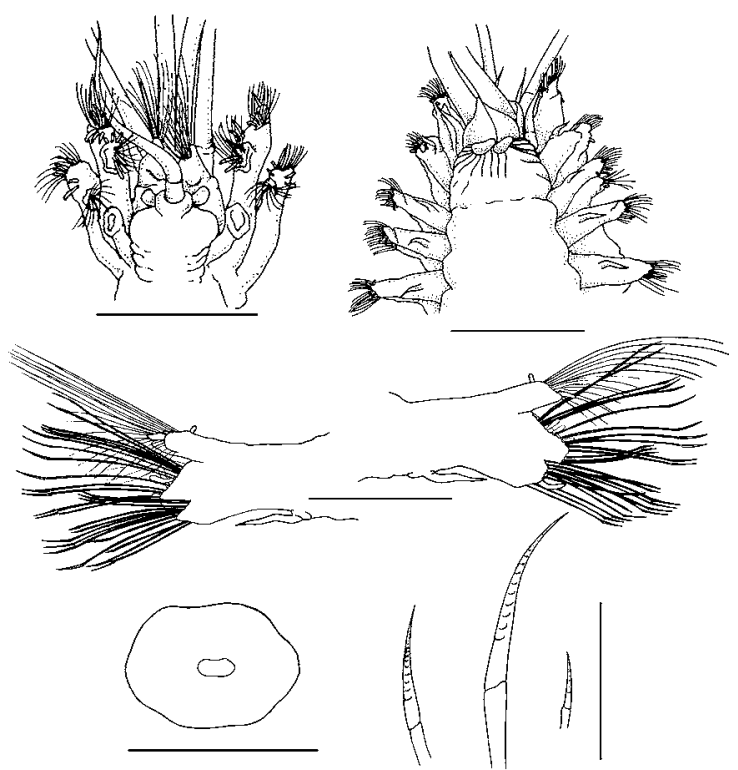

Fig. 8. Labiosthenolepis andamanensis sp. nov.: A. Anterior end, dorsal view, B. Anterior end, ventral view; C. Parapodium of segment 27, posterior view; D. Anterior view of same; E-G. Neurochaetae from same; H. Left elytron from segment 25, position of scar indicated. PMBC 20321. Scale bars $=1.0 \mathrm{~mm}$ (A-B, H), $0.5 \mathrm{~mm}(\mathrm{C}-\mathrm{D})$, and $200 \mu \mathrm{m}(\mathrm{E}-\mathrm{G})$.

Table 1. Comparison of characters of known species of Labiosthenolepis adapted from Pettibone (1992), Imajima $(2005,2006)$ and this study.

\begin{tabular}{llll}
\hline & L. laevis (McIntosh, 1885) & L. sibogae (Horst, 1917) & L. andamanensis sp. nov. \\
\hline Distribution & $\begin{array}{l}\text { South Pacific Ocean, off } \\
\text { New Zealand; West Pacific } \\
\text { coast, Japan, 5 - 549m }\end{array}$ & $\begin{array}{l}\text { Indo-Pacific, Malay } \\
\text { Archipelago, Maldives, } \\
\text { Australia, Tonga; Sagami } \\
\text { Bay, West Pacific coast, } \\
\text { Aburatsubo, Japan, 0 - 91m }\end{array}$ & $\begin{array}{l}\text { Andaman Sea, Thailand, } \\
10-42 \mathrm{~m} \text {, mud or mud with } \\
\text { sand and shells; Tanabe } \\
\text { Bay, West Pacific coast, } \\
\text { Honshu, Japan, 7.6 -14.2m }\end{array}$ \\
\hline Labial lobes & Thick, fleshy, lobulate & Oval, thin, flattened & Oval, thin, flattened \\
\hline $\begin{array}{l}\text { Stylodes on } \\
\text { dorsal sides of } \\
\text { segment 1 }\end{array}$ & Absent & Present & Present \\
\hline $\begin{array}{l}\text { Eyes } \\
\text { Anterior eyes larger than }\end{array}$ & $\begin{array}{l}\text { Anterior eyes larger than } \\
\text { posterior eyes }\end{array}$ & $\begin{array}{l}\text { Four small eyes of equal } \\
\text { size }\end{array}$ \\
\hline $\begin{array}{l}\text { Dorsal } \\
\text { tubercles on } \\
\text { segment 3 }\end{array}$ & $\begin{array}{l}\text { Small with distal papilla } \\
\text { Elytra }\end{array}$ & $\begin{array}{l}\text { Absent } \\
\text { uncovered }\end{array}$ & Small with distal papilla \\
\hline
\end{tabular}


parapodia are shorter. Articulation on the tip of ventral cirri appear only on the anterior end, and is absent on the posterior segments.

\section{Acknowledgements}

This study was supported by the Phuket Marine Biological Center (PMBC), Thailand, the Global Taxonomic Initiative (GTI) and Natural Geography In Shore Areas (NaGISA). Sincere thanks are given to Dr. Tetsuya Kato, Seto Marine Biological Laboratory, Japan for inviting me to study polychaetes (Sigalionidae) from Tanabe Bay at SMBL and to Dr. Somchai Bussarawit (PMBC) and Prof. Yoshihisa Shirayama (SMBL) for their encouragement. I express my appreciation to Dr. Danny Eibye-Jacobsen (the Zoological Museum, University of Copenhagen), Mr. Alexander I. Muir (Department of Zoology, British Museum, London, U.K), Dr. Susan J. Chambers (Department of Natural History, Royal Museum of Scotland, Scotland, U.K.), Dr. Tetsuya Kato (SMBL), Dr. Jaruwat Nabhitabhata (PMBC), and anonymous reviewers for providing valuable comments. I am grateful to the GTI/NaGISA for arranging my stay and research visit to SMBL, Japan, to Mr. Arwut Kanpet (GTI/NaGISA fellow on the same period), Ms. Mioko Matsubara, Ms. Harumi Sugino and other staff of SMBL for their generous hospitality, assistance, and making my visit more pleasant and to Mr. Niphon Phongsuwan (PMBC) for the loan of his light microscope at PMBC, Thailand. Thanks also to the staff of SEM laboratory at Prince of Songkhla University (Thailand) for their kind assistance, to Dr. Katsumi Miyazaki for his kind assistance in SEM study at SMBL and Mr. Patirat Singdum, the PMBC artist, for making the drawings. Miscellaneous contribution no. 50 from Phuket Marine Biological Center.

\section{References}

Aungtonya, C. 2002. A preliminary study of Sigalionidae (Annelida: Polychaeta) from the Andaman Sea off southwestern Thailand with an overview of presently recognized genera. Phuket Marine Biological Center Special Publication, 24, 205-235.

Aungtonya, C., Thaipal, S. and Tendal, O. 2000. A preliminary report on the Thai-Danish BIOSHELF surveys (1996-2000) of the west coast of Thailand, Andaman Sea. Phuket Marine Biological Center Research Bulletin, 63, 53-76.

Chantananthawej, B. and Bussarawit, S. 1987. Quantitative survey of the macrobenthic fauna along the west coast of Thailand in the Andaman Sea. Phuket Marine Biological Center Research Bulletin, 47, 1-23.

Horst, R. 1917. Polychaeta Errantia of the Siboga Expedition. Part 2. Aphroditidae and Chrysopetalidae. Siboga-Expeditie Uitkomsten op Zoologisch, Botanisch, Oceanographisch en Geologisch gebied verzameld in Nederlandsch Oost-Indië 1899-1900, 24b, 1-140.

Hylleberg, J., Nateewathana, A. and Bussarawit, S. 1985. Temporal changes in sediment characteristics on the west coast of Phuket Island. Phuket Marine Biological Center Research Bulletin, 37, 1-16.

Hylleberg, J., Nateewathana, A. and Chatananthawej, B. 1985. Temporal changes in the macrobenthos on the west coast of Phuket Island, with emphasis on the effects of offshore tin mining. Phuket Marine Biological Center Research Bulletin, 38, 1-32.

Imajima, M. 2005. Deep-sea benthic polychaetous annelids from around Nansei Islands. National Science Museum Monographs, No. 29, 37-99.

Imajima, M. 2006. Polychaetous annelids from Sagami Bay and the Sagami Sea, Central Japan. Memoirs of the National Science Museum, No. 40, 317-408.

McIntosh, W.C. 1885. Report on the Annelida Polychaeta collected by H.M.S. Challenger during the years 1873-1876. Report on the Scientific Results of the Voyage of H.M.S. Challenger during the years 1872-76, Zoology, 12, 1-554.

Petersen, M.E. 1998. Pholoe (Polychaeta: Pholoidae) from northern Europe: a key and notes on the nearshore species. Journal of the Marine Biological Association of the United Kingdom, 78, 1373-1376.

Pettibone, M.H. 1992. Two new genera and four new combinations of Sigalionidae (Polychaeta). Proceedings of the Biological Society of Washington, 105, 614-629.

Phasuk, B. 1992. Preliminary report on the polychaetes from the Fifth Thai-Danish Expedition along the Andaman Sea coast of Thailand. Phuket Marine Biological Center Research Bulletin, 57, 77-88.

Seidenfaden, G., Smitinand, T. and Thorson, G. 1968. Report on the fifth Thai-Danish Expedition 1966. The Natural History Bulletin of the Siam Society, 22, 245-261. 